\title{
Siyasal İletişim ve Algı Yönetimi İlişkisinin İdeolojik Açıdan Değerlendirilmesi: Selçuk Üniversitesi İletişim Fakültesi Örneği
}

\author{
Makbule Evrim Gülsünler (Doç. Dr. ) \\ Selçuk Üniversitesi İletişim Fakültesi \\ ecil@selcuk.edu.tr \\ ORCID: 0000-0003-2092-0958 \\ Şerif Tahmaz \\ Selçuk Üniversitesi Sosyal Bilimler Enstitüsü \\ serif1996@hotmail.com \\ ORCID: 0000-0002-8698-536X
}

Başvuru Tarihi: 07.11.2019

Yayına Kabul Tarihi: 26.12.2019

Yayınlanma Tarihi: 24.01.2020

DOI: http://10.17680/erciyesiletisim.643976

\section{Öz}

İnsan kendinin farkında olduğu andan itibaren, çevresiyle etkileşime girmekte ve bu etkileşimi iletişim aracılıyla gerçekleştirmektedir. Böylelikle iletişim kavramı hayatın her alanında kullanılan ve birçok disiplinle ilișkilendirilen bir kavrama dönüșmüştür. Bu kavram birçok alanda olduğu gibi siyasal alanda da kendini göstermektedir. Siyasal alanda iletişim yer alması, siyasilerin hedef kitlelerine bilgi vermeyi, onların desteklerini almayı ve onları kendi düşünceleri çerçevesinde bir araya getirmeyi sağlamaktadır. Siyasal alanda iletişim, özellikle seçim zamanlarında siyasal kampanyalar çerçevesinde yoğunlaşmaktadır. Bu yoğunlaşmanın en temel sebebi ise siyasi kişiliklerin iktidara gelme arzularıdır. Siyasilerde arzuları doğrultusunda oluşturdukları siyasal kampanyalar ile birçok iletiyi hedef kitlelerine iletmektedirler. İletilere maruz kalan hedef kitle ise, iletiyi gönderen siyasal yapıya karşı zihninde bir takım algılar oluşturmaktadır. İletilerle gelişen algının siyasal yapıya olumlu yansımaları olmalıdır. Söz konusu olumlu yansımalar, gelişi güzel bir şekilde değil planlı ve programlı bir şekilde gerçekleştirilebilir. Böylelikle siyasal iletişim alanında algı yönetimi vazgeçilmez bir olgu olarak kendini göstermektedir.

Bu nedenlerden dolayı ele aldığımız çalışmanın temel amaç ise siyasal partilerin oluşturdukları iletişim çalışmalarının hedef kitle tarafından, ideoloji açısından nasıl algılandığını ortaya koymak, siyasal iletişim kapsamında algıların oluşmasındaki iletişim araç ve yöntemlerin etki düzeylerini belirlemek ve siyasal aktörler ve organlar için belirlenen algı yönetimi kurallarının uygulanıp-uygulanmadığını belirlemektir. Bu amacı gerçekleştirmede anket tekniği ele alınmıştır. Araştırmanın evrenini Selçuk Üniversitesi İletişim Fakültesi öğrencileri oluşturmaktadır. Örneklem ise tesadüfi yöntem ile belirlenen 256 öğrenci olarak kararlaştırılmıştır. Söz konusu araştırmanın sonuçları göz önünde bulundurulduğunda TBMM'de önde gelen beş partinin, seçmen tarafından algılanan siyasal ideolojileri belirlenmeye çalışılmıştır. Siyasal algıların oluşmasında etkisi olan kitle iletişim araçlarının her birinin ayrı ayrı önemlilik düzeyleri belirlenmiş ve internetin siyasal algıların oluşmasında önemlilik düzeyinin diğer kitle iletişim araçlarına göre daha fazla olduğu gözlemlenmiştir. Bu çalışmanın önemi ise hem siyasi aktörlere ve organlara, siyasal açıdan algı yönetimi uygulamalarında fayda sağlamak hem de literatüre bu bakımdan katkıda bulunmak açısından önem arz etmektedir.

Anahtar Kelimler: Siyaset, İletişim, Algı Yönetimi. 


\title{
Ideological Aspect of the Relationship Between Political Communication and Perception Management Evaluation: Selçuk University Faculty of Communication
}

\author{
Makbule Evrim Gülsünler (Assoc. Prof. Dr.) \\ Selçuk University Faculty of Communication \\ ecil@selcuk.edu.tr \\ ORCID: 0000-0003-2092-0958 \\ Şerif Tahmaz \\ Selçuk University Institute of Social Sciences \\ serif1996_@hotmail.com \\ ORCID: 0000-0002-8698-536X
}

Date Received: 07.11.2019

Date Accepted: 26.12.2019

Date Published: 24.01.2020

DOI: http://10.17680/erciyesiletisim.643976

\begin{abstract}
From the moment one becomes aware of himself, he interacts with his environment and realizes this interaction through communication. Thus, the concept of communication has become a concept used in every field of life and associated with many disciplines. This concept manifests itself in the political field as in many other fields. Communication in the political sphere provides information to the target audience of the politicians, receives their support and brings them together within the framework of their own thoughts. Communication in the political sphere intensifies within the framework of political campaigns, especially at election times. The main reason for this concentration is the desire of political personalities to come to power. They convey many messages to their target audiences through the political campaigns they create in line with their desires. On the other hand, the target audience exposed to the messages constitutes some perceptions against the political structure that sends the message. The perception developed through messages should have positive reflections on the political structure. These positive reflections can be realized in a planned and programmed way, not in a beautiful way. Thus, perception management is an indispensable phenomenon in the field of political communication. For this reason, the main purpose of this study is to determine how the communication activities formed by political parties are perceived by the target audience in terms of ideology, to determine the effect levels of communication tools and methods in the formation of perceptions within the scope of political communication and to determine whether or not the perception management rules determined for political actors and organs are applied. to determine. The survey method has been taken into consideration in achieving this aim. The universe of the research is composed of students of Selcuk University Faculty of Communication. The sample was chosen as 256 students whose arrival was determined by good method. Considering the results of the study, the political ideologies of the five leading parties in the Turkish Grand National Assembly were determined. Significance levels of the mass media, which have an effect on the formation of political perceptions, were determined separately and it was observed that the importance level of the internet in the formation of political perceptions was higher than the other mass media.
\end{abstract}

This study is important both in terms of providing benefit to political actors and bodies in perception management practices in terms of politics and contributing to the literature in this respect.

Keywords: Politics, Communication, Perception Management 


\section{Giriş}

Algı yönetimi teknikleri, askeri, ticari, coğrafi, eğitim uygulamalarının yanında, son yıllarda siyasal dünyada da sıkça uygulanmaktadır. Siyasal aktörlerin ve organların; mesajlarını yaymak ve kitlelerini artırmak için mesajlarını ve pazarlama planlarını algı yönetimi tekniklerini kullanarak geliştirmektedirler. Bu bağlamda algı yönetimi siyasal aktörler ve organlar için vazgeçilmez bir olgu olarak karşımıza çıkmakta olduğu görülmektedir (Bakan ve Kefe, 2012, s.30). Söz konusu olan vazgeçilemez olan siyasal iletişim ve algı yönetimi ilişkisi; siyasal arenada karmaşık ve yoğun mesaj alış-verişi içerisinde olan siyasal aktör ve liderlerin, bulundukları siyasal iletişim ortamında kendilerinin ön plana çıkmalarını ve yenilik yaparak tercih edilmelerini sağlamak adına yapılan bir takım çalışmalara da katkıda bulunmaktadır (Özçelik, 2015, s.1).

Siyasal iletişim ve algı yönetiminin bir diğer önemi ise seçmenlerin artık vaatler çerçevesinde değil algıladıkları imaja göre oy kullanma eyleminde bulundukları ve algıladıkları imaja göre bir tutum oluşturmalarıdır (Başsoy, 2011, s.21). Bu bağlamda bakıldığında algılanan imajı ve algılama sonucunda oluşan tutumu, şekillendirebilmek ve kontrol altına alabilme için siyasal aktör ve organlar siyasal iletişim çalışmalarında algı yönetiminin stratejilerinden ve uygulamalarında faydalanmaktadır (Özodaşık, 2009, s.80).

Siyasal alanda çalıșma yapan algı yöneticilerinin en temel amacı, siyasi politikalarının gereklerini yerine getirebilmek için iletişimin her türlü teknik ve unsurlarından yararlanmaktadır. Burada gayri meşru unsurlardan da yararlanılabilmektedir. Dolayısıyla bu son husus, algılama yöneticilerine yöneltilen eleştirilerin en başında gelmektedir (Çelik, 2018, s.435). Söz konusu olan bu durumun nedeni siyasal iletişimde algilama yönetimi kavramı yeni bir kavram olduğundan etik kuralların tam olarak oturmamış olmasındandır (Özçelik, 2015, s.75). Ancak bu alanda yapılan çalışmaların, giderek yoğunlaşmaya başlanması ve bu alana ilişkin profesyonel bir şekilde çalışmaların yapılıyor olması zaman içerisinde etik kuralların oturacağına işareti olarak görmek yanlış olmayacaktır. Ancak yapılan bu çalışmalara rağmen siyasal iletişim ve algı yönetimine ilişkin stratejiler ve uygulamalar literatür açısından oldukça azdır. Bu sebepten dolayı ele aldığımız bu çalışma literatüre önemli katkılarda bulunacaktır.

Söz konusu çalışmada siyasal iletişim çerçevesinde ideoloji kavramı ve siyasal iletişimin algı yönetimiyle ilişkisi teorik açıdan ele alınmıştır. Daha sonrasında ise araştırmanın temel konusunu oluşturan, Selçuk Üniversitesi İletişim Fakültesi öğrencilerinin algılarına yönelik araştırmanın amacından, öneminden, sınırlılıklarından, yönteminden ve bulgularından bahsedilmiştir.

\section{Siyasal İletişim ve Algı Yönetimi iliş̧kisi}

Siyasal iletişim ve algı yönetimi ilişkisini ele almadan önce bu iki kavramın ne olduğunu ifade etmek konunun daha iyi anlaşılması açısından fayda sağlayacaktır. Öncelikle siyaset kavramı insanoğlunun var olduğu andan itibaren kendi göstermektedir. Bu bağlamda bakıldığında siyaset kavramı insan ile yaşıt toplumsal bir kurumdur. Siyaset, tarih boyunca üzerinde tartışılan ve konuşulan bir kavramdır. Bu tartışmaların temeli bundan 2500 yll kadar öncesine, Antik Yunan düşüncesine dek uzanır. Bu alanda Platon'un "Devlet ve Aristoteles'in Politika" adlı eserleri siyaset konusunda bugün bile önemsenen klasik kaynaklardır. Hem Ortaçağ İslam ve Hıristiyan düşüncesinde, hem de bu dönemden sonra günümüze kadar siyaset konusunda önemli bir bilgi birikiminin var olduğu açıtır. Ancak bağımsız bir bilimsel disiplin olarak siyaset bilimi de pek çok diğer sosyal bilim gibi 
on dokuzuncu yüzyılda ortaya çıkmıştır. Siyaset felsefesi alanında bugüne kadar üretilen birikim göz önünde bulundurulursa, siyaset biliminin köklerinin çok eskiye dayandığ ve bu alanın önemli bir bilgi ve düşünce birikiminin mirasçısı olduğu açıkça ortadadır. $\mathrm{Bu}$ bilgi ve düşünce birikiminin temelinde ise toplumsal değerlerin ve kıt kaynakların paylaşılması çabasından kaynaklanan çatışmadır (Damlapınar ve Balcı, 2005, s.17, Canbey: 2009, s.33). Çatışmalara neden olan siyaset kavramını tanımlamak gerekir ise iktidar kavramını inceleyen; devlet, ülke, toplum yönetimini ele alan; bilim, sanat ve hatta meslek olma özelliği taşıyan bir olgu olarak ifade edilmektedir (Berberoğlu, 1997:3). Bir başka tanımlama da ise toplumların iktidar ulaşmak için gerçekleştirdiği faaliyetleri düzenleyen genel-geçer kuralları koymak, korumak ve değiştirmek için sürekli olarak gerçekleştirdikleri faaliyetlerin bütünü olarak tanımlanmaktadır (Heywood, 2006, s.24). Bu tanımlamayı çoğaltmak mümkündür ancak siyasetin tanımı üzerinde bir uzlaşma olmadığı gibi konusu üzerinde de, bilim insanları arasında tam bir görüş birliğinin varlığından söz etmek zordur. Kimilerine göre konu yalnızca devletle sinırlıdır. Ama çoğunluk, daha geniş bir kavram olan iktidardan hareket etmektedir (Kışlalı, 2002, s.18).

Siyaset kavramının devletle mı yoksa iktidarla mı açıklanması tartışma konusu olmasına rağmen siyasetin olduğu her yerde iktidar mücadelesinin varlığı göz ardı edilemez bir gerçektir. Siyasal aktörlerin söz konusu mücadeleyi ele alabilmesi için siyasal anlamda iletişim faaliyetlerinde bulunması gerekmektedir. Bu gerekliliğin temelinde mücadeleyi kazandıracak kitle üzerinde egemenlik kurulması ve kitlenin olumlu anlamda etkilenmesi yatmaktadır. Kitleler üzerinde egemenlik kurulabilmesi için bir takım harekete geçiren iletiler gönderilmelidir. Bu iletilerin sağlıklı bir şekilde gönderilmesi ise iletişim tekniklerinin bilinmesi ve doğru zamanlama ile uygulamasıyla gerçekleştirilebilir. Bu bağlamda bakıldığında siyaset kavram ile gerçekleştirilmek istenen durumun, iletişim tekniklerine ihtiyaç duyduğu görülmektedir. Böylelikle siyasal arenada siyasal iletişim kavramı kendini göstermektedir (Kılıçaslan, 2008, s.8). Siyasal iletişim kavramı ise siyasal ortamda bireylerin birbirini karşılıklı olarak anlama ve anlatma biçimi olduğunu ifade etmekte ve bu sürecin iki yönlü bir iletişim çabası olduğunu vurgulamaktadır (Kentel, 1991, s.41). Bir başka tanımlamada ise siyasal iletişim, siyasal aktörlerin belli ideolojik amaçlarını, politikalarını belli gruplara, kitlelere, ülkelere ya da bloklara kabul ettirmek ve gerektiğinde eyleme dönüştürmek, uygulamaya koymak üzere çeşitli iletişim tür ve tekniklerini kullanmaları şeklinde tanımlanmaktadır (Aziz, 2013, s.3). Lakin siyasal iletişim sadece hedef kitlelere veya gruplara istenilen iletileri en etkili bir şekilde ulaştırmakla kalmaz aynı zamanda siyasal örgüt ve organlar içersin de koordinasyonu ve etkileşimi sağlayarak siyasetin etkili, başarılı ve doğru bir işleyişini de sağlamaktadır (Baysal, 2010, s.29-30). Siyasal iletişim tanımlamalarda yer verilen işlevlerini gerçekleştirebilmek için birçok farklı kavramdan yararlanmaktadır. Bunların içerisinde en dikkat çekeni ise algı yönetimi kavramıdır.

Algı, beynin çeşitli duyulardan gelen bilgi karmaşası içinden anlamlı örüntüler yorumlamasıdır (Morris, 2002, s. 121) Algılama yönetimi kavramı ise ilk kez, ABD Savunma Bakanlığı içindeki birimlerce kullanılmıştır. Her ne kadar algılama yönetimi psikolojinin temel başlıklarından biri olarak düşünülse de pek çok bilimsel alan ile ilintilidir. Söz konusu algı yönetimi, ABD siyasi kararlarını ülkede ve tüm dünya kamuoyunda benimsenmesi için kullanılan bir yöntem olarak ortaya atılmıştır (Saydam, 2012, s.78).

ABD siyasal hayatında kullanılan, algılama yönetimi kavramını ifade etmek gerekir ise algı yönetimi, tanıma işleviyle ortaya çıkan, bireylerin içsel ve dışsal özelliklerine yönelerek 
oluşturulan algı mekanizmasını yönetsel süreçte uygulayan bir anlayıștır (Uğurlu, 2004, s.40). Bir başka tanımlamada algı yönetimi, birey ve toplumların davranış, düşünce, kabul ve tepkiselliklerinin yani reseptif ve reaksiyoner kimliklerinin elde edilmek istenilen sonuca odaklı olarak biçimlendirilmesi, kalıplanması bir başka yaklaşımla kendilerine empoze edilen değerleri satın almaları olarak tanımlamıştır (Çitlioğlu, 2012, s. 39). Tanımlamalardan yola çıkarak algı yönetimini örgüt dışına aktarılan enformasyonu kontrol etmek ve geliştirerek hedef kitleye sunmak olarak ifade edilebilir (Saydam, 2012, s. 81).

Algıyı yönetmekle görevlendirilen kişi ya da birimler algı yönetimin tanımında yer verilen durumları gerçekleştirmek için çok sayıda yöntem ve adım izlemektedir. Öncelikle herhangi bir konuda ikna edilmesi, değiștirilmesi ve etkilenmesi gereken hedef kitle ayrıntılı olarak analiz edilmekte, güçlü ve zayıf yanları ortaya konulmakta ve hassas noktalar tespit edilmektedir. Daha sonra elde edilen sonuçlara göre sloganlar ve propaganda temaları geliştirilmektedir. Bu aşamada medyanın da oyuna dâhil edilmesi ile birlikte sanal gerçeklikler oluşturulmakta ve dolayısıyla gerçek ile kurgu arasında ayrım yapılması zorlaştırılmaktadır. Bu durum Amerikalı Siyasetçi Henry Kissinger tarafından "Bir şeyin gerçek olması pek o kadar önemli değildir; fakat gerçek olarak algılanması çok önemlidir" şeklinde dile getirilmiştir (Öksüz, 2013, s.13).

Algı yönetimi genel olarak dört aşamadan oluşmaktadır: Hedef kitlenin dikkatinin çekilmesi; hedef kitlenin dikkatini kontrol altında tutmak için benzer bilgilerin sunulması ve paylaşılması; sunulan bilginin hedef kitlenin algılarıyla tutarlı hale getirilmesi, bilginin aynı pozisyonda kalması için iletişim kaynaklarında tekrar edilmesidir (Callamari ve Reveron, 2003, s. 2).

Algı yönetiminin tanımlamaları ve izlenecek adımlarıyla ulaşılmak istenen amaçları, Siegel'e üç temel başlığa ayırmıştır. Bunlardan ilki meşruiyet kazanmak ve sürdürmek için yurtiçinde ve yurtdışında hedef kitlenin desteğini oluşturmak ve korumaktır. İkincisi ise faaliyetlerin sonuçlarını tam olarak anlamlandırmak için muhaliflere veya üçüncü taraflara yüksek derecede güvenilirlik kurmak amacıyla niyet ve hedefleri iletmektir. Son olarak yerel halkların, algı yönetimini uygulayanın hedeflerine uygun olarak hareket etmeleri için tutumlarını ve davranışlarını etkilemek olarak ifade edilmiştir. (Siegel, 2005, s.118-119 akt: Payam, 2018, s.21). Siyasal aktörler ve organlar, algı yönetimini bu üç temel amacına ihtiyaç duyduğundan siyasal iletişim çalışmalarında algı yönetimine yer vermekteler. $\mathrm{Bu}$ durum ise siyasal iletişim ile algı yönetimini ilişkilendirmemize neden olmaktadır.

Siyasal iletişim ve algı yönetimi arasındaki ilişkinin en temel kaynağı iknadır. Her iki disiplinde hedeflediği kitleyi belirli bir düşünce ışığında yönlendirmek ve ikna etmek üzerine çalışmalar yürütmektedir. Bu bağlamda hem algı yönetimi hem de siyasal iletişim davranış şekilleri oluşturmak ve temel amaçlara ulaşmak için kullanılan araç konumundadırlar (Türk, 2014, s.16). Söz konusu durumu siyasal iletişim çerçevesinde düșündügümüzde, hedef kitlenin siyasal aktör veya organ tarafından ikna edilebilmesi için hedef kitlenin mevcut algısını bilmek gerekmektedir. Algıların bilinmesi gerekliliği siyasal iletişimi, algıları yönetmek için kullanılan en önemli araçlardan biri yapmaktadır. Siyasal iletişimin temel amacının, seçmenin desteğini alarak iktidar olma arzusudur. Bu durumu gerçekleştirmek için ise hedef kitlesini ikna etmek ve onlarda istenilen davranışı yaratmak gerekliliğinden siyasal iletişim çalışmaları algı yönetimine ihtiyaç duymaktadır (Kazu, 2018, s. 110). 
Siyasal iletişim algı yönetimine ihtiyaç duymasının sebebi, az öncede bahsettiğimiz gibi hedef kitlesinin mevcut algılarını ortaya koymak ve mevcut algıyı yönlendirmektir. Lakin algıyı yönetmek, iletişimi yönetmek ve yönlendirmek olarak görülmektedir. Algı yönetimi çerçevesinde iletişimi yönetmek ve yönlendirmek ise siyasal açıdan istenilen davranışı biçimlendirmemize, temel hedef ulaşmamıza, siyasal imajımızı güçlendirmemize ve siyasal fikrin hedef kitleye yayılmasına yardımcı olacaktır. Bu durum siyasal iletişim ve algı yönetimi ilişkisinin temel noktasıdır. Siyasal iletişim ve algı yönetimi kapsamında gerçekleştirilen bu hedefler hem siyasal aktörü veya organı temel hedefi olan iktidara ulaşma arzusuna kavuşturur hem de seçmen karşısından siyasal yapının değeri artar ve kriz durumunda iyi niyet ortamı oluşturur. Dolayısıyla iyi ve doğru zamanlama ile planlanmış, siyasal çerçevede algı yönetimi uygulamaları nihai hedefe ulaşmada siyasal aktör ve organlara fayda sağlayacaktır (Türk ve Bıyık, 2009, s.326-327).

Siyasal iletişim çerçevesinde başarılı bir algı yönetimi uygulayabilmesi, yani hedeflenen kitlenin algılarını doğru bir şekilde yönetilmesi için stratejilerin doğru bir şekilde belirlenmesi ve uygulanması gerekmektedir. Söz konusu stratejilerin uzun vadede ve toplumun tamamı olmasa da büyük bir kısmına hitap edecek şekilde dizayn edilmelidir. Bu durum siyasal aktörü veya organı başarıya ulaştırabilmekte ve önemini arttırmaktadır (Kazu, 2018, s.110). Saydam ise algı yönetimi kapsamında bireylerin veya çeşitli örgütlerin başarıya ulaşması için 11 tane temel kurul belirlemiştir. Bu kuralları şu şekilde sıralamak mümkündür (Saydam, 2012, s.205-353).

- Hedef kitlenin değerline uyulması ve çalışmaların bu kapsamda gerçekleştirilmesi,

- Hedef kitlenin kültürel değerlerine özen gösterilmesi ve önemsenmesi

- Hedef kitlenin beklentileri üzerine bir yaklaşım benimsenmesi,

- Hedef kitlenin kafalarının karıştırılmaması, açık ve yalın olunması,

- Uygulanan çalışmanın sonucuna odaklanılması,

- Kesinlikle yapılan çalışmanın ölçülmesi,

- Çalışmalar ve uygulamalar gerçekliğe dayandırılmalı,

- Yapılan çalıșmalar belirli aralıklar ile tekrar edilmeli,

- Söz konusu olan farklılaşmalar yönetilebilmeli,

- Çalışmalar ev uygulamalar düşünceden yani mantıktan çok duygulara hitap ediyor olmalıdir.

Siyasal anlamda algı yönetimi çalışmaları ve uygulamalarına en güzel örneklerinden biride $\mathrm{ABD}$ ve Vietnam savaşıdır. ABD’nin birinci ve ikinci dünya savaşındaki başarısı ABD’nin askeri ve siyasal anlamda güçlü bir imaj algısı oluşturmasını sağlamıştır. 19551975 yıllarına gelindiğinde ise ABD'lerinin Vietnam'a karşı olan savaşı kaybetmesi çizmiş olduğu güçlü imaj algısını zedelemiştir. ABD ise bu durumu kendi lehine çevirebilmek ve hedef kitlesi nazarında zedelenmiş olan güçlü imaj algısını toparlayabilmek için algı yönetimi teknik ve stratejilerine yönelmiştir. Bu yönelimi sinema ve medya çerçevesinde gerçekleștirmiş ve uygulamaya koymuştur. Sinema ve medyayı kullanması o dönemki en güçlü algı araçlarının olması ve bu araçları elinde bulunduruyor olmasıdır. Sinema ve medya araçlarıyla ABD 'Rambo' tarzı filmler çekerek bu filmleri medya ile hedef kitlesine aktarmıştır. Böylelikle ABD askerlerinin Vietnam'da korkusuzca savaştığını ve savaşı aslında ABD’nin kazandığı gibi bir algı oluşturmuştur. Böylelikle ABD oluşturmuş olduğu, güçlü siyasal ve askeri imaj algısını korumuş hatta daha da güçlendirmiştir (www.tarihiolaylar.com). 
Siyasal iletişim ve algı yönetimi sadece dış hedef kitleye yönelik değil aynı zamanda siyasal örgütün iç hedef kitlesine yönelikte uygulanmaktadır. İç hedef kitleye uygulanmasının sebebi, siyasal örgüt içerisindeki bir takım eksiklikler iç hedef kitleyi algılarına göre bu eksiklikleri kapatmaya itmektedir. Algılara göre eksiklikleri giderme ise bazen örgüt içerisinde çatışmalara neden olmada ve söz konusu siyasal örgütün temel amacına ulaşmada engel teşkil etmektedir. Doğal olarak bu durum ise siyasal örgütlenmeyi iç hedef kitleye yönelikte algı çalışmaları yapmaya yönlendirmektedir (Özer, 2008, s. 18). $\mathrm{Bu}$ bağlamda siyasal aktörler ve örgütler iç-diş çevresiyle kurmuş olduğu iletişimin kapsamında algıyı iyi yönetebilmek için çevresini iyi bilgilendirmeli, yönlendirmeli ve denetleyici olmalıdır. Siyasal aktör ve örgütler hakkında yeterli bilgi edinememiş, gerekli düzeyde iletişim kuramamış kişilerin veya kitlelerin ilgili siyasal aktör ve örgüte yönelik olumlu bir algıya sahip olmaları çok zordur. Siyasal aktör ve örgütlere yönelik olumlu algıların oluşması için Tutar, Saydam'dan da etkilenerek bir takım kurallar belirlemiştir. Bu kurallar ise şu şekildedir (Tutar, 2008, s. 109-111; Saydam, 2005, s. 90).

- Çalışmanın sonuçlarını etkileyebilecek paydaşlar belirlenmelidir.

- Organizasyonun farklılı̆̆ını ortaya koyacak güçlü yanları tespit edilmelidir.

- İç ve dış paydaşlara verilecek mesajlar belirlenmelidir.

- Mesaj verilecek kitlenin öncelikle var olan algılarının tespit edilmesi gerekmektedir. Daha sonra belirlenen mesajların iletilmesi ve mesajlarının etkilerinin ölçülebilir sonuçların elde edilmesi zorunludur.

- Mevcut iletişim akımlarının ve metotlarının algıyı nasıl etkileyeceğinin belirlenmesi gerekmektedir.

- Algı yönetiminde iletişim çift yönlü olmalıdır. Yani hem mesaj iletilmeli hem de karşı taraf dinlenilmelidir.

- Başarılı bir algı yönetimi için ortak akıl oluşturulması faydalı olacaktır.

Geliştirilen bu kurallara rağmen algı yönetimi uygulayıcıları ve yöneticileri tam olarak bu kurallara uymamaktadır. Özelliklede siyasal anlamda çalışma yapan algılama yöneticileri bu anlamda kendini göstermektedir. Bu yöneticiler için temel amaç siyasi politikalarının gereklerini yerine getirmek için iletişimin her türlü teknik ve unsurlarından yararlanmaktır. Burada gayrı meşru unsurlardan da yararlanılabilmektedir. Dolayısıyla bu son husus algılama yöneticilerine yöneltilen eleştirilerin en başında gelmektedir (Çelik, 2018, s. 435). Söz konusu olan bu durumun nedeni siyasal iletişimde algılama yönetimi kavramı yeni bir kavram olduğundan etik kuralların tam olarak oturmamış olmasındandır (Özçelik, 2015, s. 75). Lakin bu alanda çalışmaların giderek yoğunlaşmaya başlanması ve bu alana ilişkin profesyonel bir şekilde çalışmaların yapılıyor olması zaman içerisinde etik kuralların oturacağına işareti olarak görmek yanlış olmayacaktır. Bu alanda Akif Özer'in "Siyasal İletişimin Etkinliğinde Algllama Yönetiminin Rolü”, Balcı, Şükrü \& Bekiroğlu, Onur "Türkiye'de Siyasal Kampanya Uygulamaları" başlıklı çalışmaları alandaki çalışmalar örnek gösterilebilir.

Son zamanlarda ise siyasal iletişim çerçevesinde algılama yönetimi kurallarının siyasal alanda rekabeti daha da arttırmış ve bu alana ilişkin faaliyetlerin çeşitlenmesini sağlayarak bir farkındalık oluşturmuştur. Çünkü algıları yönetenlerin başarılı olduğu kavranmış ve bu alanda faaliyeti olan her partinin ve liderin vazgeçilmezi haline gelmiştir. Bu bağlamda siyasal iletişimde algılama yönetimi "Hedef kitleyi istenilen bir fikir ve amaç üzerinde rıza gösterecekleri bir inanma ve ikna olma sürecine getirmek" (Akay, 2014, s.30) şeklinde tanımlanabilir. Seçmenlerin kendilerini tanımladıkları 
siyasi tercihleriyle, konuşmalardaki ikna ve üslup faktörlerini değerlendirmelerinde bir farklılaşma olup olmadığına ilişkin yapılan araştırmada faktör ortalamalarından hareketle, kendini demokrat ve sosyal demokrat olarak niteleyenlerin çatışmacı üsluptan ziyade uzlaşmacı üsluba yönelik eğilimlerinin daha yüksek düzeyde olduğu belirlenmiști (Başarır, 2016, s. 102).

Günümüzde görünümler ve imajlar ideolojilerden ve sorunlardan daha önemli hale gelmişlerdir. Politikacıların ve basının yarattığı yeni unsurlar artık gerçekleri değiştirmeye değil, sürekli olarak algılamayı yönetmeye odaklaşmaktadırlar. Ancak bu sürecin açık ve net olduğunu düşünmek te bizleri yanıltabilir. Çünkü ne düşündügümüzü ve neyi bildiğimizi şekillendiren güçler daima görünür olmazlar ve ne anlama geldiklerini veya söylediklerinin ne anlama geldiklerini veya söylediklerinin ne anlamı olduğunu ortaya koymaya gerek duymazlar (Schechter, 2006: 2). Bu durum başarılı bir algılama yöneticisi için sahip olunması gereken özelliklerden birisidir

\section{Selçuk Üniversitesi İletişim Fakültesi Öğrencilerin Siyasal Algılarına Yönelik Araştırma}

$\mathrm{Bu}$ araştırmada, siyasal iletişim çerçevesinde oluşan algıların daha çok hangi iletişim araç ve yöntemleriyle oluştuğu, siyasal iletişim çalışmaları kapsamında oluşturulan algı yönetimi kurallarına uyulup uyulmadığı ve Türkiye Büyük Millet Meclisinde (TBMM) milletvekili bakımında önde olan beş siyasal partinin ideoloji açısından mevcut algılarının neler olduğu ifade edilmeye çalışılmıştır. Söz konusu araştırma, Selçuk Üniversitesi İletişim Fakültesi öğrencileri üzerinde yapılmıştır. Bu bölümde ise araştırmanın amacı, önemi, sınırlılıkları, yöntemi ve bulgular yer almaktadır.

\subsection{Araştırma Amacı ve Önemi}

Siyasal aktörlerin ve organların en temel amacı olan iktidara gelme arzusu için, siyasal iletişim çalışmaları yürüten bireyler birçok farklı disiplinden yararlanmaktadır. $\mathrm{Bu}$ disiplinlerin içerisinde en dikkat çekeni ise algı yönetimi kavramıdır. Algı yönetimi, siyasal açıdan kullanımının en temel sebebi olumlu bir algı biçimlendirilmesi ile güçlü bir imaj oluşturmaktır. Siyasal iletişim çalışmaları yapan bireyler sadece imaj yönetimi için değil aynı zamanda halkla ilişkiler, ikna, reklam ve propaganda çalışmaları içinde algı yönetimine başvurmaktadır. Bu bağlamda ele aldığımız araştırmada TBMM'nde yer alan ve milletvekili sayısı bakımında önde olan Adalet ve Kalkınma Partisi (AKP), Cumhuriyet ve Halk Partisi (CHP), Milliyetçi ve Hareket Partisi (MHP), IYYI PARTİ ve Halkların Demokratik Partisi (HDP)'nin (TBMM.gov.tr) mevcut algılarının neler olduğu ve seçmenin 2019 yerel seçimlerinde siyasal kampanyalara yönelik algılarının da neler olduğu ifade edilmeye çalışılmaktadır. Böylelikle bu araştırma hem siyasal aktörler, siyasal organlar ve seçmen için hem de literatüre katkı sağlamak açısından önem arz etmektedir. Söz konusu araştırmada Selçuk Üniversitesi İletişim Fakültesi öğrencilerin siyasal kampanyalara yönelik algılarını, siyasal algılarının oluşmașında etkili olan iletişim araç ve yöntemlerini ve siyasi partilerin ideoloji çerçevesindeki mevcut algılarını ortaya koymak amaçlanmaktadır.

\subsection{Araştırma Sınırlılıkları}

Araştırmanın sınırlılıkları şu şekilde ifade etmek mümkündür.

- Araştırmanın evreni açısından Selçuk Üniversitesi İletişim Fakültesi öğrencileri ile sinırlı kalmıştır.

- Araştırma, veri toplama aracı olan anket formu ile sınırlandırılmıştır. 
- Araştırmanın süresi kapsamında (29 Nisan-17 Haziran 2019) bir sınırlılık söz konusudur.

\subsection{Araştırmanın Yöntemi}

Araștırmada veri toplama yöntemi olarak yüz yüze anket yöntemi kullanılmıștır. Böylelikle sorulan sorularla ilgili olarak araştırmaya katılanların zihninde oluşabilecek yanlış anlaşılmalar ve ortaya çıkabilecek yanlışlıklar giderilmeye çalışılmıştır. Ayrıca anket tekniği, doğrudan doğruya yanıtlayanın doldurması gereken bir soru kâğıdına dayandırılmış bir veri derleme tekniğidir. Anket, birincil kaynaklardan bilgi toplamak için, hazırlanan sistematik bir soru formudur. Amacl, araştırmanın problemini çözecek ve ele alınan hipotezleri test edecek bilgileri sistematik bir biçimde toplamak ve saklamaktır(Büyüköztürk, Akgün ve vd. 2008, s.45). Bu sebebiyetlerden dolayı araştırmada anket yönteminin kullanılması söz konusu siyasal algıların ölçülmesinde fayda sağlayacaktır.

\subsubsection{Araştırmanın Modeli}

Selçuk Üniversitesi İletişim Fakültesi öğrencilerinin siyasal algılarını belirlemeye yönelik bu araştırma nicel verilere dayalı genel tarama modeli ve ilişkisel tarama modeli kapsamında bir araştırmadır.

\subsubsection{Araştırma Evreni ve Örneklemi}

Araştırmanın evrenini, Selçuk Üniversitesi İletişim Fakültesinde öğrenim gören öğrenciler oluşturmaktadır. Alınan verilere göre Selçuk Üniversitesi İletişim Fakültesinin öğrencilerinin toplam sayısı 2866 olarak tespit edilmiştir. Yazıcıoğlu ve Erdoğan (2004, s.50) tarafından hazırlanan örneklem Büyüklükleri $(\alpha=0.05)$ tablosu dikkate alınarak örneklem büyüklüğü \pm 0.05 örneklem hatası $p=0,8$ ve $q=0,2$ güven aralığ olarak belirlenmiştir. Yapılan inceleme sonucunda Selçuk Üniversitesi İletişim Fakültesi öğrencilerinin oluşturduğu 2866 kişilik bu evreni, tesadüfi örneklem yöntemi ile belirlenen 256 kişiden oluşacak bir örneklem grubunun temsil edebileceği öngörülmektedir.

\subsubsection{Anket Formu ve Veri Analizi}

Anket formunda ilk olarak 2019 yerel seçimlerine katılıp katılmadığı sorulmuştur. Daha sonrasında araştırmaya katılanlara siyasal tercihlerinin ve fikirlerinin oluşmasında hangi iletişim yöntemlerinin ve araçlarının etkili olduğunu görebilmek için 5'li likert ölçeği kullanılarak 8 tane soru sorulmuştur. Burada katılımcılara verilen seçenekler 'çok önemsiz', 'önemsiz', 'kararsızım', 'önemli' ve 'çok önemli' seçenekleridir. Sonrasında ise siyasal açıdan algı yönetimi çalışmalarında uyulması gereken kurallara, siyasal aktörler ve organlar tarafından doğru bir şekilde icra edilip edilmediğini tespit edebilmek için yine 5'li likert yönetimi kullanılarak 6 tane soru katılımcılara yöneltilmiştir. Katılımcılara sunulan seçenekler ise 'kesinlikle katılmıyorum', 'katılmıyorum', 'kararsızım', 'katılıyorum' ve 'kesinlikle katılıyorum' seçenekleridir. Araştırmaya katılanların siyasal algılarının oluşmasında etkili olan etmenleri belirleye bilmek için çoktan seçmeli 1 soru yöneltilmiştir. Sonrasındaki 6 soru ise TBMM'de yer alan ve milletvekili sayısı bakımından önde olan 5 partinin siyasal ideoloji çerçevesinde mevcut algılarını ifade edebilmek için sorulan çoktan seçmeli sorulardır. Son 5 soru ise ankete katılan katılımcıların sosyo-demografik özelliklerini belirlemek adına sorulan sorulardır. Toplamda ise anket formunda 25 soru yer almaktadır. Bu sorulardan bazılarına verilen cevaplar çalışmaya eklenememiştir. $\mathrm{Bu}$ durumun nedenleri ise bazı sorulardan elde edilen verilerden anlamlı ilişkilerin kurulamaması ve çalıșmanın belirli bir sayfa sınırlılığının bulunması olarak ifade edilebilir. 
Anket formu, Özçelik'in (2015, s.210-112) Ali Saydam'ın algı yönetimi kurallarından etkilenerek oluşturduğu anket formu ile Gölbaşı'nın (2010,s. 336) kullanmış olduğu anket formu incelenerek oluşturulmuştur. Ayrıca siyasal partilerin ideoloji açısında mevcut algılarını ölçebilmek adına sorular türetilerek anket formuna eklenmiştir. Anket 256 kişiye uygulanmış ve SPSS 15 paket programı kullanılarak veriler bilgisayar ortamına aktarılmıștır. Elde edilen veriler ile frekans, yüzde ve çapraz tablolamalar yapılmıștır.

\subsubsection{Araştırma Soruları}

Araștırma kapsamında değerlendirilecek araştırma sorularını şu şekilde sıralamak mümkündür.

- Araştırma sorusu 1: TBMM'nde bulunan ve üye sayısı bakımından önde olan 5 siyasal partinin ideoloji çerçevesinde mevcut algıları nelerdir?

- Araştırma sorusu 2: Siyasal algıların oluşumunda hangi kitle iletişim araçları daha önemli bir role sahiptir?

- Araştırma sorusu 3: Öğrenim görülen alanlara göre siyasal algıların oluşmasında aile ve yakın çevrenin rolü nelerdir?

\subsection{Araştırma Bulguları}

Bu bölümde araştırmaya katılan katılımcıların, siyasal açıdan algı yönetimi kurallarına yönelik sorulara verdikleri cevapları, siyasal algıların oluşmasında etken olan iletişim araç ve yöntemlerine yönelik cevapları ve TBMM'de milletvekili bakımından önde olan 5 siyasal partinin ideoloji çerçevesinde mevcut algılarına yönelik cevaplarına yer verilmiştir. Çalışma yapılırken sosyo-demografik özellikler sorulmuş lakin sayfa sınırlaması nedeniyle eklenememiștir.

\subsubsection{Siyasal Açıdan Algı Yönetiminin Kurallarına Yönelik Bulgular}

$\mathrm{Bu}$ başlık altında siyasal algı yönetiminin kurallarına yönelik sorulara, katılımcıların vermiş oldukları cevapların bulguları yer almaktadır.

Tablo 1: "Seçmenin Değerlerine Uygun Bir Kampanya Yürütülmüştür" Yargısının Katılım Düzeyi

\begin{tabular}{|l|l|c|c|c|c|}
\hline \multicolumn{2}{|l|}{} & Frekans & Yüzde & Gerçek Yüzde & YığıImalı Yüzde \\
\hline \multirow{7}{*}{} & KESINLIKLE KATILMIYORUM & 25 & 9,8 & 9,9 & 9,9 \\
\cline { 2 - 6 } & KATILMIYORUM & 29 & 11,3 & 11,5 & 21,3 \\
\cline { 2 - 6 } & KARASIZIM & 84 & 32,8 & 33,2 & 54,5 \\
\cline { 2 - 6 } & KATILIYORUM & 89 & 34,8 & 35,2 & 89,7 \\
\cline { 2 - 6 } & KESINLIKLE KATILIYORUM & 26 & 10,2 & 10,3 & 100,0 \\
\cline { 2 - 6 } & Toplam & 253 & 98,8 & 100,0 & \\
\cline { 2 - 6 } & Kayıp Veri & 3 & 1,2 & & \\
\hline \multirow{2}{*}{ Toplam } & 256 & 100,0 & & \\
\hline
\end{tabular}

Araştırmaya katılan katılımcılara yöneltilen ve siyasal algı yönetimi kurallarından biri olan "seçmenin değerlerine uygun bir kampanya yürütülmüştür" yargısına katılım düzeyini şu şekilde ifade etmek mümkünüdür. Söz konusu yargıya toplamda 253 katılımcı cevap verir iken 3 katılımcı bu yargıya her hangi bir cevap vermemiştir. Bunların yüzde 9,9'ünün kesinlikle katılmadığını, yüzde 11,5'şının katılmadıklarını, yüzde 33,2'sinin karasız kaldıklarını, yüzde 35,2'sinin katıldığını ve yüzde 10,3'ünün kesinlikle katıldığını ifade etmektedir. Buradan yola çıkarak siyasal kampanyaların seçmenin değerlerine uygun olarak yürütülmesine yönelik yargıya katılımcıların çoğu katıldığını ifade etse de birçoğu da karasız kaldığı görülmektedir. 
Tablo 2: "Seçmenin Kültürüne Özen Gösterilmiștir" Yargısının Katılım Düzeyleri

\begin{tabular}{|l|l|c|c|c|c|}
\hline \multicolumn{2}{|c|}{} & Frekans & Yüzde & Gerçek Yüzde & Yığılmalı Yüzde \\
\hline \multirow{7}{*}{} & KESINLIKLE KATILMIYORUM & 25 & 9,8 & 9,9 & 9,9 \\
\cline { 2 - 6 } & KATILMIYORUM & 29 & 11,3 & 11,5 & 21,3 \\
\cline { 2 - 6 } & KARASIZIM & 63 & 24,6 & 24,9 & 46,2 \\
\cline { 2 - 6 } & KATILIYORUM & 102 & 39,8 & 40,3 & 86,6 \\
\cline { 2 - 6 } & KESINLIKLE KATILIYORUM & 34 & 13,3 & 13,4 & 100,0 \\
\cline { 2 - 6 } & Toplam & 253 & 98,8 & 100,0 & \\
\cline { 2 - 6 } & Kayıp Ver & 3 & 1,2 & & \\
\hline \multirow{2}{*}{ Toplam } & 256 & 100,0 & & \\
\hline
\end{tabular}

"Siyasal kampanyalarda seçmenin kültürüne özen gösterilmiştir" yargısına katılım düzeyini şu şekilde ifade etmek mümkündür. Araştırmaya katılan katılımcıların bahsi geçen yargıyı, 253 tanesi cevaplamış ve 3 tanesi cevaplamamıştır. Cevaplayanların yüzde 9,9'ü kesinlikle katılmadıklarını, yüzde 11,5'i katılmadıklarını, yüzde 24,9'ü kararsız kaldıklarını, yüzde 40,3'ü katıldıklarını ve yüzde 13,4'ü kesinlikle katıldıklarını ifade etmişlerdir. $\mathrm{Bu}$ bulgular çerçevesinde düşünüldüğünde katılımcıların çoğunun "siyasal kampanyalarda seçmenin kültürüne özen gösterilmiştir" yargısına katıldığı gözlemlenmektedir.

Tablo 3: "Siyasal Kampanyaların Diğer Rakiplerden Farklılaşarak Yöneltilmiştir" Yargısının Katılım Düzeyi

\begin{tabular}{|l|l|c|c|c|c|}
\hline \multicolumn{2}{|l|}{} & Frekans & Yüzde & Gerçek Yüzde & Yığılmalı Yüzde \\
\hline \multirow{7}{*}{} & KESINLIKLE KATILMIYORUM & 31 & 12,1 & 12,3 & 12,3 \\
\cline { 2 - 6 } & KATILMIYORUM & 32 & 12,5 & 12,6 & 24,9 \\
\cline { 2 - 6 } & KARASIZIM & 76 & 29,7 & 30,0 & 54,9 \\
\cline { 2 - 6 } & KATILIYORUM & 76 & 29,7 & 30,0 & 85,0 \\
\cline { 2 - 6 } & KESINLIKLE KATILIYORUM & 38 & 14,8 & 15,0 & 100,0 \\
\cline { 2 - 6 } & Toplam & 253 & 98,8 & 100,0 & \\
\cline { 2 - 6 } & Kayıp Veri & 3 & 1,2 & & \\
\hline Toplam & 256 & 100,0 & & \\
\hline
\end{tabular}

"Siyasal kampanyaların diğer rakiplerden farklılaşarak yönetilmiştir" yargısına katılım düzeyini şu șekilde ifade etmek mümkündür. Söz konusu yargıya katılım düzeyini belirten katılımcı sayısı 253 iken katılım düzeyini belirtmeyen katılımcı sayısı sadece 3'dür. Katılım düzeylerini belirten katılımcıların yüzde 12,3'ü kesinlikle katılmamakta, yüzde 12,6'si katılmamakta, yüzde 30'ü karasız kalmakta, aynı şekilde yüzde 30'ü katılmakta ve yüzde 15’i kesinlikle katılmaktadır. Bu bulgular doğrultusunda yürütülen siyasal kampanyaların diğer rakiplerden farklılaşarak yönetilmesi yargısına katılımcıların hem karasız kaldıkları hem de katıldıkları gözlemlenmektedir.

\subsubsection{Siyasal Algıların Oluşumunda Etkili Olan Araç ve Yöntemlere Yönelik Bulgular}

$\mathrm{Bu}$ başlıkta siyasal açıdan algıların oluşumunda hangi araç ve yöntemlerin daha etkili olduğuna yönelik bulgulara yer verilmiştir. 
Tablo 4: Siyasal Algıların Oluşumunda Televizyonun Önemine Yönelik Bulgular

\begin{tabular}{|l|c|c|c|c|}
\hline & Frekans & Yüzde & Gerçek Yüzde & Yığılmalı Yüzde \\
\hline ÇOK ÖNEMSiz & 30 & 11,7 & 11,7 & 11,7 \\
\hline ÖNEMSiz & 30 & 11,7 & 11,7 & 23,4 \\
\hline KARARSIZIM & 76 & 29,7 & 29,7 & 53,1 \\
\hline ÖNEMLi & 61 & 23,8 & 23,8 & 77,0 \\
\hline ÇOK ÖNEMLi & 59 & 23,0 & 23,0 & 100,0 \\
\hline Toplam & 256 & 100,0 & 100,0 & \\
\hline
\end{tabular}

Araştırmaya katılan katılımcılar, televizyonun siyasal algıların oluşmasındaki etkisini şu şekilde ifade etmektedir. Katılımcıların yüzde 11,7'si çok önemsiz görmekte, yüzde 11,7'si önemsiz görmekte, yüzde 29,7'si konu hakkında karasız kaldığını ifade etmekte, yüzde 23,8'i önemli görmekte ve yüzde 23'ü çok önemli görmektedir. Buradan yola çıkarak araştırmaya katılan bireylerin çoğu televizyonun siyasal algıların oluşumundaki etkisi hakkında kararsız kaldığı görülmektedir.

Tablo 5: Siyasal Algıların Oluşumunda Gazetenin Önemine Yönelik Bulgular

\begin{tabular}{|l|l|c|c|c|c|}
\hline \multicolumn{2}{|l|}{} & Frekans & Yüzde & Gerçek Yüzde & Yığılmalı Yüzde \\
\hline \multirow{7}{*}{} & ÇOK ÖNEMSiz & 31 & 12,1 & 12,2 & 12,2 \\
\cline { 2 - 6 } & ÖNEMSiz & 47 & 18,4 & 18,4 & 30,6 \\
\cline { 2 - 6 } & KARARSIZıM & 77 & 30,1 & 30,2 & 60,8 \\
\cline { 2 - 6 } & ÖNEMLi & 68 & 26,6 & 26,7 & 87,5 \\
\cline { 2 - 6 } & ÇOK ÖNEMLI & 32 & 12,5 & 12,5 & 100,0 \\
\cline { 2 - 6 } & Toplam & 255 & 99,6 & 100,0 & \\
\cline { 2 - 6 } & Kayıp Veri & 1 &, 4 & & \\
\hline \multirow{2}{*}{ Toplam } & 256 & 100,0 & & \\
\hline
\end{tabular}

Tabloda da görüldügü üzere, araştırmaya katılan katılımcılar, siyasal algıların oluşumunda gazetenin önemini şu şekilde ifade etmektedirler. Katılımclların yüzde 12,2'isi çok önemsiz görmekte, yüzde 18,4'ü önemsiz görmekte, yüzde 30,2'si konu hakkında karasız kaldığını ifade etmekte, yüzde 26,7'si önemli görmekte ve yüzde 12,5'i çok önemli görmektedir. Buradan yola çıkarak katılımcılar, siyasal algıların oluşumunda gazetenin etkisini hakkında karasız kaldıklarını ifade etmektedirler lakin azımsanamayacak kadar da gazeteyi önemli görenlerde mevcuttur.

Tablo 6: Siyasal Algıların Oluşumunda Radyonun Önemine Yönelik Bulgular

\begin{tabular}{|l|l|c|c|c|c|}
\hline \multicolumn{2}{|l|}{} & Frekans & Yüzde & Gerçek Yüzde & Yığılmalı Yüzde \\
\hline \multirow{7}{*}{} & ÇOK ÖNEMSiz & 67 & 26,2 & 26,3 & 26,3 \\
\cline { 2 - 6 } & ÖNEMSiz & 66 & 25,8 & 25,9 & 52,2 \\
\cline { 2 - 6 } & KARARSIZIM & 74 & 28,9 & 29,0 & 81,2 \\
\cline { 2 - 6 } & ÖNEMLI & 29 & 11,3 & 11,4 & 92,5 \\
\cline { 2 - 6 } & ÇOK ÖNEMLI & 19 & 7,4 & 7,5 & 100,0 \\
\cline { 2 - 6 } & Toplam & 255 & 99,6 & 100,0 & \\
\cline { 2 - 6 } & Kayıp Veri & 1 &, 4 & & \\
\hline \multirow{2}{*}{ Toplam } & 256 & 100,0 & & \\
\hline
\end{tabular}

Araştırmaya katılan katılımcıların, radyonun siyasal algıların oluşumundaki önemliliği konusundaki görüşleri şu şekildedir. Katılımcıların yüzde 26,3'ü çok önemsiz görmekte, yüzde 25,9'ü önemsiz görmekte, yüzde 29'ü konu hakkında karasız olduğunu belirmekte, yüzde 11,4'ü önemli görmekte ve yüzde 7,5'i çok önemli görmektedir. Bu bulgular kapsamında radyonun siyasal algıların oluşumundaki etkisi hakkında katılımcılar karasız 
olduklarını ifade etmektedirler lakin azımsanamayacak kadar radyoyu çok önemsiz görenlerde mevcuttur.

Tablo 7: Siyasal Algıların Oluşumunda Miting ve Gezilerin Önemine Yönelik Bulgular

\begin{tabular}{|l|l|c|c|c|c|}
\hline \multicolumn{2}{|l|}{} & Frekans & Yüzde & Gerçek Yüzde & Yığılmalı Yüzde \\
\hline \multirow{7}{*}{} & ÇOK ÖNEMSiz & 34 & 13,3 & 13,4 & 13,4 \\
\cline { 2 - 6 } & ÖNEMSiz & 34 & 13,3 & 13,4 & 26,8 \\
\cline { 2 - 6 } & KARARSIZIM & 42 & 16,4 & 16,5 & 43,3 \\
\cline { 2 - 6 } & ÖNEMLi & 67 & 26,2 & 26,4 & 69,7 \\
\cline { 2 - 6 } & ÇOK ÖNEMLI & 77 & 30,1 & 30,3 & 100,0 \\
\cline { 2 - 6 } & Toplam & 254 & 99,2 & 100,0 & \\
\cline { 2 - 6 } & Kayıp Veri & 2 &, 8 & & \\
\hline \multirow{3}{*}{ Toplam } & 256 & 100,0 & & \\
\hline
\end{tabular}

Siyasal algıların oluşumunda miting ve gezilerin etkisini, araştırmaya katılan katılımcılar şu şekilde ifade etmektedirler. Katılımcıların yüzde 13,4'ü çok önemsiz görmekte, yüzde 13,4'ü önemsiz görmekte, yüzde 16,5'i konu hakkında karasız olduklarını belirtmekte, yüzde 26,4'ü önemli görmekte ve yüzde 30,3'ü çok önemli görmektedir. Bu bağlamda bakıldığında siyasal algıların oluşumunda miting ve gezilerin etkisinin çok önemli olduğu görülmektedir.

Tablo 8: Siyasal Algıların Oluşumunda İlan ve Broșürlerin Önemine Yönelik Bulgular

\begin{tabular}{|l|l|c|c|c|c|}
\hline \multicolumn{2}{|l|}{} & Frekans & Yüzde & Gerçek Yüzde & Yığılmalı Yüzde \\
\hline \multirow{7}{*}{} & ÇOK ÖNEMSiz & 63 & 24,6 & 24,8 & 24,8 \\
\cline { 2 - 6 } & ÖNEMSiz & 68 & 26,6 & 26,8 & 51,6 \\
\cline { 2 - 6 } & KARARSIZIM & 61 & 23,8 & 24,0 & 75,6 \\
\cline { 2 - 6 } & ÖNEMLI & 35 & 13,7 & 13,8 & 89,4 \\
\cline { 2 - 6 } & ÇOK ÖNEMLI & 27 & 10,5 & 10,6 & 100,0 \\
\cline { 2 - 6 } & Toplam & 254 & 99,2 & 100,0 & \\
\cline { 2 - 6 } & Kayıp Veri & 2 &, 8 & & \\
\hline \multirow{2}{*}{ Toplam } & 256 & 100,0 & & \\
\hline
\end{tabular}

Tabloda da görüldüğü üzere siyasal algıların oluşumunda ilan ve broşürlerin etkisini araștırmaya katılan bireyler şu şekilde ifade etmektedirler. Katılımcıların yüzde 24,8'i çok önemsiz görmekte, yüzde 26,8'i önemsiz görmekte, yüzde 24'ü konu hakkında karasız kaldıklarını ifade etmekte, yüzde 13,8'i önemli görmekte ve yüzde 10,6'si çok önemsiz görmektedir. Buradan yola çıkarak siyasal algıların oluşumunda ilan ve broşürlerin önemsiz olduğu gözlemlenmektedir.

Tablo 9: Siyasal Algıların Oluşumunda Kamuoyu Araştırmalarının Önemine Yönelik Bulgular

\begin{tabular}{|l|l|c|c|c|c|}
\hline \multicolumn{2}{|l|}{} & Frekans & Yüzde & Gerçek Yüzde & YığıImalı Yüzde \\
\hline \multirow{2}{*}{} & ÇOK ÖNEMSiz & 28 & 10,9 & 11,0 & 11,0 \\
\cline { 2 - 6 } & ÖNEMSiz & 38 & 14,8 & 15,0 & 26,0 \\
\cline { 2 - 6 } & KARASIZIM & 48 & 18,8 & 18,9 & 44,9 \\
\cline { 2 - 6 } & ÖNEMLI & 69 & 27,0 & 27,2 & 72,0 \\
\cline { 2 - 6 } & ÇOK ÖNEMLI & 71 & 27,7 & 28,0 & 100,0 \\
\cline { 2 - 6 } & Toplam & 254 & 99,2 & 100,0 & \\
\cline { 2 - 6 } & Kayıp Veri & 2 &, 8 & & \\
\hline \multirow{2}{*}{ Toplam } & 256 & 100,0 & & \\
\hline
\end{tabular}

Siyasal algıların oluşumunda kamuoyu araştırmalarının etkisini araştırmaya katılan katılımcılar şu şekilde ifade etmektedirler. Katılımcıların yüzde 11'i çok önemsiz 
görmekte, yüzde 15’i önemsiz görmekte, yüzde 18,9'ü konu hakkında karasız kaldığını ifade etmekte, yüzde 27,2'si önemli görmekte ve yüzde 28'i çok önemli görmekte olduğunu ifade etmektedir. Bu bağlamda düşünüldügüünde siyasal algıların oluşmasında kamuoyu araştırmalarının çok önemli olduğu görülmektedir.

Tablo 10: Siyasal Algıların Oluşumunda İnternetin Önemine Yönelik Bulgular

\begin{tabular}{|l|l|c|c|c|c|}
\hline \multicolumn{2}{|l|}{} & Frekans & Yüzde & Gerçek Yüzde & YığıImalı Yüzde \\
\hline \multirow{7}{*}{} & ÇOK ÖNEMSiz & 12 & 4,7 & 4,7 & 4,7 \\
\cline { 2 - 6 } & ÖNEMSiz & 20 & 7,8 & 7,8 & 12,5 \\
\cline { 2 - 6 } & KARASIZIM & 32 & 12,5 & 12,5 & 25,1 \\
\cline { 2 - 6 } & ÖNEMLi & 66 & 25,8 & 25,9 & 51,0 \\
\cline { 2 - 6 } & ÇOK ÖNEMLI & 125 & 48,8 & 49,0 & 100,0 \\
\cline { 2 - 6 } & Toplam & 255 & 99,6 & 100,0 & \\
\cline { 2 - 6 } & Kayıp Veri & 1 &, 4 & & \\
\hline \multirow{2}{*}{ Toplam } & 256 & 100,0 & & \\
\hline
\end{tabular}

Siyasal algıların oluşmasında internetin önemini araştırmaya katılan bireyler şu şekilde ifade etmektedirler. Katılımcıların yüzde 4,7'si çok önemsiz görmekte, yüzde 7,8'i önemsiz görmekte, yüzde 12,5'i konu hakkında karasız kaldığını ifade etmekte, yüzde 25,9'ü önemli görmekte ve yüzde 49'ü çok önemli gördüklerini belirtmektedir. Söz konusu bulgular göz önünde bulundurulduğunda siyasal algıların oluşmasında yüzde 49'lük bir oranla internetin çok önemli olduğu ifade edilmektedir.

Tablo 11: Siyasal Algının Oluşmasında Aile ve Yakın Çevre İle Kurulan İletişimin Etkisinin Öğrenim Görülen Alanlara göre Değişiminin Çapraz Tablolaması

\begin{tabular}{|c|c|c|c|c|c|c|c|}
\hline & \multicolumn{5}{|c|}{$\begin{array}{l}\text { Siyasal Algının Oluşmasında Aile ve Yakın } \\
\text { Çevre İle Kurulan İletişimin Etkisi }\end{array}$} & \multirow{3}{*}{$\begin{array}{c}\text { Toplam } \\
66 \\
\end{array}$} \\
\hline & & $\begin{array}{c}\text { Çok } \\
\text { Önemsiz }\end{array}$ & Önemsiz & Kararsızım & Önemli & $\begin{array}{c}\text { Çok } \\
\text { Önemli }\end{array}$ & \\
\hline \multirow{8}{*}{$\begin{array}{l}\text { HANGI BOLUMDE } \\
\text { OKUMAKTASINIZ }\end{array}$} & \multirow{2}{*}{$\begin{array}{l}\text { HALKLA İLişKILER } \\
\text { VE TANITIM }\end{array}$} & 6 & 9 & 20 & 19 & 12 & \\
\hline & & $9,1 \%$ & $13,6 \%$ & $30,3 \%$ & $28,8 \%$ & $18,2 \%$ & $100,0 \%$ \\
\hline & \multirow{2}{*}{ REKLAM } & 12 & 4 & 18 & 15 & 12 & 61 \\
\hline & & $19,7 \%$ & $6,6 \%$ & $29,5 \%$ & $24,6 \%$ & $19,7 \%$ & $100,0 \%$ \\
\hline & \multirow{2}{*}{ GAZETECILIK } & 7 & 13 & 9 & 21 & 11 & 61 \\
\hline & & $11,5 \%$ & $21,3 \%$ & $14,8 \%$ & $34,4 \%$ & $18,0 \%$ & $100,0 \%$ \\
\hline & \multirow{2}{*}{$\begin{array}{l}\text { RADYO TELEVIZYON } \\
\text { VE SINEMA }\end{array}$} & 9 & 18 & 24 & 8 & 7 & 66 \\
\hline & & $13,6 \%$ & $27,3 \%$ & $36,4 \%$ & $12,1 \%$ & $10,6 \%$ & $100,0 \%$ \\
\hline \multirow{2}{*}{\multicolumn{2}{|c|}{ Toplam }} & 34 & 44 & 71 & 63 & 42 & 254 \\
\hline & & $13,4 \%$ & $17,3 \%$ & $28,0 \%$ & $24,8 \%$ & $16,5 \%$ & $100,0 \%$ \\
\hline
\end{tabular}

Yukarıdaki tabloda da görüldügü üzere halkla ilişkiler ve tanıtım alanında öğrenim gören ve araştırmaya katılan katılımcıların, siyasal algıların oluşmasında aile ve yakın çevre ile kurulan iletişiminin önemlilik düzeyini yönelik cevaplarını şu şekilde ifade etmek mümkündür. Katılımcıların yüzde 9,1'i çok önemsiz görmekte, 13,9'ü önemsiz görmekte, yüzde 30,3'ü karasız kaldığını ifade etmekte, yüzde 28,9'ü önemli görmekte ve yüzde 18,2'si çok önemli görmektedir. Reklam alanında öğrenim gören katılımcılar da bu durum şu şekildedir. Katılımcıların yüzde 19,7'si çok önemsiz görmekte, yüzde 6,6'si önemsiz görmekte, yüzde 29,5'i konu hakkında karasız kalmakta, yüzde 24,6'si önemli görmekte ve yüzde 19,7'si çok önemli görmektedir. Gazetecilin alanında ise bu durum şu şekilde kendini göstermektedir. Katılımclların yüzde 11,5'i çok önemsiz görmekte, yüzde 21,3'ü önemsiz görmekte, yüzde 14,8'i konu hakkında karasız kaldığını ifade 
etmekte, yüzde 34,4'ü önemli görmekte ve yüzde 18'i çok önemli görmektedir. Son olarak ise radyo, televizyon ve sinema alanında öğrenim gören katılımcıların yüzde 13,6'si çok önemsiz görmekte, yüzde 27,3'ü önemsiz görmekte, yüzde 36,4'ü konuyla alakalı karasız kaldıklarını ifade etmekte, yüzde 12,1' önemli görmekte ve yüzde 10,6'si çok önemli görmekte olduğunu ifade etmektedir. Bu bulgular ışığında bir genelleme yapmak gerekir ise halkla ilişkiler ve tanıtım, reklam ve radyo, televizyon ve sinema alanında öğrenim gören katılımcılar, siyasal algıların oluşmasında aile ve yakın çevre ile kurulan iletişimin etkisi ile ilgili olarak karasız olduklarını ifade etmektedirler. Lakin gazetecilik alanında öğrenim gören katılımcılar ise söz konusu etkinin önemli olduğunu belirtmektedirler.

\subsubsection{TBMM'de Bulunan 5 Partinin Siyasal İdeoloji Açısından Mevcut Algılarına Yönelik Bulgular}

Burada TBMM'sinde bulunana ve milletvekili bakımından önde olan 5 partinin, siyasal ideoloji açısından mevcut algılarına dönük bulgulara yer verilmeye çalışılmıştır. Siyasal partilerin milletvekili sayıları sırasıyla şu şekildedir; AKP (291), CHP (139), HDP (62), MHP (49) ve iyi partidir (39) (TBMM.gov.tr). Bu partilerin siyasal ideoloji çerçevesindeki algıları, Muhafazakârlık, Milliyetçilik, Atatürkçülük, Sosyal demokrat, Kominizim ve Liberalizm bakımından ele alınacaktır.

Tablo 12: Partilerin Muhafazakârlık Algılarına Yönelik Bulgular

\begin{tabular}{|c|c|c|c|}
\hline & & Frekans & Yüzde \\
\hline \multirow{6}{*}{$\begin{array}{l}\text { SÖZ KONUSU OLAN } \\
\text { PARTILERDEN } \\
\text { HANGILERININ } \\
\text { MUHAFAZAKÂR OLDUĞUNU } \\
\text { DÜŞÜNMEKTESINIZ? }\end{array}$} & AKP & 196 & $61,4 \%$ \\
\hline & CHP & 14 & $4,4 \%$ \\
\hline & MHP & 60 & $18,8 \%$ \\
\hline & HDP & 1 & ,3\% \\
\hline & IYYI PARTi & 15 & $4,7 \%$ \\
\hline & DíĞER & 33 & $10,3 \%$ \\
\hline \multicolumn{2}{|l|}{ Toplam } & 319 & $100,0 \%$ \\
\hline
\end{tabular}

*Çoktan seçmeli soru olduğundan dolayı frekans toplamı örneklemin hacmini geçmektedir.

Yukarıdaki tabloda da görüldüğü üzere araștırmaya katılan katılımcıların, TBMM'de yer alan ve milletvekili bakımından önde olan, 5 siyasal partinin muhafazakârlık algısına ilişkin yüzdelerini şu şekilde ifade etmek mümkündür. Katılımcıların vermiş oldukları cevapların yüzde 61,4'ü AKP'nin, yüzde 4,4'ü CHP'nin, yüzde 18,8'i MHP'nin, yüzde 0,3'ü HDP'nin, yüzde 4,7'si iyi partiyi ve yüzde 10,3'ü diğer partilerin muhafazakâr olduğunu ifade etmektedir. Bu veriler kapsamında yüzde 61,4 gibi yüksek bir oranla AKP'nin muhafazakâr bir algıya sahip olduğu ifade edilebilir. Söz konusu bu soruya cevap veren katılımcı sayısı 251 iken cevap vermeyen katılımcı sayısı ise sadece 5'dir.

Tablo 13: Partilerin Milliyetçilik Algılarına Yönelik Bulgular

\begin{tabular}{|c|c|c|c|}
\hline & & Frekans & Yüzde \\
\hline \multirow{6}{*}{$\begin{array}{l}\text { SÖZ KONUSU OLAN } \\
\text { PARTILERDEN } \\
\text { HANGILERININ } \\
\text { MiLLIYYTCI OLDUǦUNU } \\
\text { DÜŞÜNMEKTESINIZ? }\end{array}$} & AKP & 15 & $4,5 \%$ \\
\hline & CHP & 32 & $9,6 \%$ \\
\hline & MHP & 199 & $59,4 \%$ \\
\hline & HDP & 16 & $4,8 \%$ \\
\hline & IYYI PARTI & 57 & $17,0 \%$ \\
\hline & DiĞER & 16 & $4,8 \%$ \\
\hline \multicolumn{2}{|l|}{ Toplam } & 335 & $100,0 \%$ \\
\hline
\end{tabular}

Yukarıdaki tabloda da görüldüğü üzere araştırmaya katılan katılımcıların, TBMM'de yer alan ve milletvekili bakımından önde olan, 5 siyasal partinin milliyetçilik algılarına 
ilişkin yüzdelerini şu şekilde ifade etmek mümkündür. Katılımcıların vermiş oldukları cevapların yüzde 4,5'i AKP'nin, yüzde 9,6'si CHP'nin, yüzde 59,4'ü MHP'nin, yüzde 4,8'i HDP'nin, yüzde 17'si İYİ partiyi ve yüzde 4,8'i diğer partilerin milliyetçi bir yapıya sahip olduğunu ifade etmektedir. Bu bağlamda düşünüldüğünde yüzde 59,4 ile MHP'nin milliyetçi bir algıya sahip olduğu gözlemlenmektedir. Söz konusu bu soruya cevap veren katılımcı sayısı 253 iken cevap vermeyen katılımcı sayısı ise sadece 3'dür.

Tablo 14: Partilerin Atatürkçülük Algılarına Yönelik Bulgular

\begin{tabular}{|c|c|c|c|}
\hline & & Frekans & Yüzde \\
\hline \multirow{6}{*}{$\begin{array}{l}\text { SÖZ KONUSU OLAN PARTILERDEN } \\
\text { HANGILERININ ATÜRKÇÜ } \\
\text { OLDUĞUNU DÜŞÜNMEKTESINIZ? }\end{array}$} & AKP & 10 & $2,9 \%$ \\
\hline & CHP & 200 & $59,0 \%$ \\
\hline & MHP & 58 & $17,1 \%$ \\
\hline & HDP & 2 & ,6\% \\
\hline & IYYi PARTi & 54 & $15,9 \%$ \\
\hline & DiĞER & 15 & $4,4 \%$ \\
\hline \multicolumn{2}{|l|}{ Toplam } & 339 & $100,0 \%$ \\
\hline
\end{tabular}

Araştırmaya katılan katılımcılar TBMM'de yer alan ve milletvekili bakımından önde olan 5 siyasal partinin Atatürkçü algısını, katılımcıların vermiş oldukları cevapların oranına göre şu şekilde ifade etmek mümkündür. Katılımcıların vermiş oldukları cevapların yüzde 2,9'ü AKP'nin, yüzde 59'ü CHP'nin, yüzde 17,1'i MHP'nin, yüzde 0,6'si HDP'nin, yüzde 15,9'ü iyi partiyi ve yüzde 4,8'i diğer partilerin Atatürkçü bir yapıya sahip olduğunu ifade etmektedir. Buradan yola çıkarak yüzde 59 ile CHP'nin Atatürkçü bir algıya sahip olduğu görülmektedir. Söz konusu soruya cevap veren katılımcı sayısı 251 iken soruya cevap vermeyen katılımcı sayısı ise 5 'dir.

Tablo 15: Partilerin Sosyal Demokrat Algılarına Yönelik Bulgular

\begin{tabular}{|c|c|c|c|}
\hline & & Frekans & Yüzde \\
\hline \multirow{6}{*}{$\begin{array}{l}\text { SÖZ KONUSU OLAN PARTILERDEN } \\
\text { HANGILERININ SOSYAL DEMOKRAT } \\
\text { OLDUǦUNU DÜŞÜNMEKTESINIZ? }\end{array}$} & AKP & 44 & $15,3 \%$ \\
\hline & CHP & 111 & $38,5 \%$ \\
\hline & MHP & 27 & $9,4 \%$ \\
\hline & HDP & 18 & $6,3 \%$ \\
\hline & IYYI PARTI & 53 & $18,4 \%$ \\
\hline & DiĞER & 35 & $12,2 \%$ \\
\hline \multicolumn{2}{|l|}{ Toplam } & 288 & $100,0 \%$ \\
\hline
\end{tabular}

*Çoktan seçmeli soru olduğundan dolayı frekans toplamı örneklemin hacmini geçmektedir

Bahsi geçen siyasal partilerin sosyal-demokrat algılarına yönelik sorulan soruya, araștırmaya katılan katılımcıların cevaplarının oranlarını şu şekilde ifade etmek mümkündür. Katılımcıların verdikleri cevaplara göre, yüzde 15,3'ü AKP'nin, yüzde 38,5'i CHP'nin, yüzde 9,4'ü MHP'nin, yüzde 6,3'ü HDP'nin, yüzde 18,4'ü IYYİ partiyi ve yüzde 12,2 'si diğer partilerin sosyal demokrat bir yapıya sahip olduğunu ifade etmektedir. Bu bulgular doğrultusunda yüzde 38,5 ile CHP'nin sosyal demokrat bir algıya sahip olduğu gözlemlenmektedir. Söz konusu soruya katılım ise şu şekildedir. Katılımcıların 234'ü soruyu cevaplamış iken 22 katılımcı herhangi bir cevap vermemiștir. 
Tablo 16: Partilerin Komünist Algılarına Yönelik Bulgular

\begin{tabular}{|c|c|c|c|}
\hline & & Frekans & Yüzde \\
\hline \multirow{6}{*}{$\begin{array}{l}\text { SÖZ KONUSU OLAN PARTILERDEN } \\
\text { HANGILERININ KOMÜNIST } \\
\text { OLDUĞUNU DÜŞÜNMEKTESINIZ? }\end{array}$} & AKP & 5 & $1,7 \%$ \\
\hline & CHP & 35 & $12,0 \%$ \\
\hline & MHP & 7 & $2,4 \%$ \\
\hline & HDP & 105 & $36,1 \%$ \\
\hline & IYYI PARTi & 7 & $2,4 \%$ \\
\hline & DiĞER & 132 & $45,4 \%$ \\
\hline \multicolumn{2}{|l|}{ Toplam } & 291 & $100,0 \%$ \\
\hline
\end{tabular}

Tablodan da anlaşılacağı üzere araştırmaya katılan katılımcıların, hangi siyasal partileri komünist algıladıklarına ilişkin soruya verdikleri cevapların bulgularını şu şekilde ifade etmek mümkündür. Katılımcıların verdikleri cevaplara göre, yüzde 1,7'si AKP'nin, yüzde 12'si CHP'nin, yüzde 2,4'ü MHP'nin, yüzde 36,1'i HDP'nin, yüzde 2,4'ü İYİ partinin ve yüzde 45,4'ü diğer partilerin komünist bir yapıya sahip olduğunu ifade etmektedir. Buradan yola çıkarak TBMM'de yer alan partiler arasında yüzde 36,1 oranı ile HDP'nin komünist bir algıya sahip olunduğu düşünülmektedir. Lakin TBMM'nin dışında yer alan diğer partilerin yüzde 45,4'lük oran ile HDP'den daha çok komünist bir yapıya sahip olunduğu gözlemlenmekte. Bahsi geçen soruya katılım ise şu şekildedir. Katılımcıların 242'ü soruyu cevaplamış iken 14 katılımcı herhangi bir cevap vermemiștir.

Tablo 17: Partilerin Liberalizm Algılarına Yönelik Bulgular

\begin{tabular}{|c|c|c|c|}
\hline & & Frekans & Yüzde \\
\hline \multirow{6}{*}{$\begin{array}{l}\text { SÖZ KONUSU OLAN PARTILERDEN } \\
\text { HANGILERININ LiBERALISt } \\
\text { OLDUĞUNU DÜŞÜNMEKTESINIZ? }\end{array}$} & AKP & 91 & $28,1 \%$ \\
\hline & CHP & 64 & $19,8 \%$ \\
\hline & MHP & 40 & $12,3 \%$ \\
\hline & HDP & 14 & $4,3 \%$ \\
\hline & IYYi PARTi & 49 & $15,1 \%$ \\
\hline & DiĞER & 66 & $20,4 \%$ \\
\hline \multicolumn{2}{|l|}{ Toplam } & 324 & $100,0 \%$ \\
\hline
\end{tabular}

Yukarıdaki tabloda da görüldügü üzere araştırmaya katılan öğrencilerin TBMM'de yer alan ve milletvekili bakımından önde olan, 5 siyasal partinin liberaliz algısına ilişkin yüzdelerini șu şekilde ifade etmek mümkündür. Katılımcıların vermiş oldukları cevapların yüzde 28,1'i AKP'nin, yüzde 19,8'i CHP'nin, yüzde 12,3'ü MHP'nin, yüzde 4,3'ü HDP'nin, yüzde 15,1'i İYİ partiyi ve yüzde 20,4'ü diğer partilerin liberaliz bir algısının olduğunu ifade etmektedir. Bu veriler kapsamında yüzde 28,1 oranıyla AKP'nin liberaliz bir algıya sahip olduğu ifade edilebilir. Ancak oranların birbirleriyle yakınlığı düșünüldüğünde bu durumun keskin bir șekilde ortada olduğu düșünülemez. Söz konusu bu soruya cevap veren öğrenci sayısı 235 iken cevap vermeyen öğrenci sayısı ise 21'dir.

\section{Sonuç ve Öneriler}

Siyasal iletişim ve algı yönetiminin ilişkisini ele aldığımız bu araştırmada, siyasal aktör ve organların en temel amacı olan iktidara gelme arzusu için birçok alandan faydalandığını görmekteyiz. Bu alanlar hakla ilişkiler, reklam, propaganda, imaj yönetimi, algı yönetimi vb. alanlardan oluşmaktadır. Söz konusu alanlardan en dikkat çekeni ise hiç şüphesiz algı yönetimi kavramıdır. Siyasal arenada farklılaşmak ve siyasal algıları yönlendirmek için algı yönetimine ihtiyaç duyulmaktadır. Bu ihtiyacın yanında siyasal iletişim çalışanları, 
halkla ilişkiler, imaj, reklam, ikna vb. alanlarda da yaptığı çalışmalarda algı yönetiminin tekniklerinden ve uygulamalarından yararlanmaktadırlar. Yani siyasi aktörler veya organlar, sadece algı yönetimini doğrudan kullanmamakta aynı zamanda birçok farklı disiplini kullanırken de algı yönetimi uygulamalarından faydalanmaktadır. Söz konusu faydalanma ise hem siyasal aktörlerin ve organların hem de akademisyenlerin dikkatini çekmektedir. Bu nedenden dolayı ele aldığımız araştırmanın bulgularını genel olarak şu şekilde ifade etmek mümkündür.

Söz konusu araştırmada, siyasal algıların oluşmasında etkili olan araçları ve yönetmeleri belirlemeye yönelik soruları, araştırmaya katılan katılımcılar şu şekilde yanıtlamışlardır. Siyasal algıların oluşmasında, önemsiz gördükleri araç olarak ilan ve broşürler olduğu görülmektedir. Daha sonrasında ise televizyonun, gazetenin ve radyonun siyasal algıların oluşmasındaki etkisi açısından karasız kaldıklarını gözlenmektedir. Araştırmaya katılan katılımcıların siyasal algıların oluşmasında çok önemli gördükleri araçlar ve yöntemler ise, siyasal aktör ve organların düzenlediği miting ve geziler, kamuoyu araştırmaları ve internet olduğunu ifade etmektedirler. Burada en dikkat çeken husus ise interneti siyasal algıların oluşmasında çok önemli görenler, araştırmaya katılanların neredeyse yarısı seviyesindedir. Dolayısıyla siyasal açıdan algı yönetimi strateji ve teknikleri uygulanırken internet aracından faydalanmak, istenilen amaca ulaşmada fazlasıyla katkı sağlayacaktır.

Siyasal aktörler ve organlar açısından önemli olan bir diğer husus ise siyasal ideoloji bakımından partilerinin mevcut algılarıdır. Söz konusu araştırmaya katılan kişiler siyasal partilerin ideolojilerini şu şekilde ifade etmektedirler. Araştırmaya katılanlarının çoğunun AKP'nin muhafazakâr bir algıya sahip olduğunu ifade ettiği gözlemlenmektedir. Araştırmaya katılan katılımcılar, MHP'nin milliyetçi bir algıya sahip olduğunu ifade etmekte, CHP'nin ideolojik açısından mevcut algısını, hem sosyal-demokrat hem de Atatürkçü olarak belirtmektedirler. Araştırmaya katılanlar komünist olarak HDP'yi nitelendirilmektedir. Son olarak ise liberal bir algıya sahip parti olarak AKP ifade edilmekte lakin diğer partilerin liberal görünme yüzdelerinin AKP’ye yakınlığı göz önünde bulundurulduğunda, AKP'nin liberal algısı çok keskin bir şekilde ifade edilememektedir. Yapılan araştırmada elde edilen bu bulgular ele alındığında araştırma sorularının cevapları ise şu şekilde ifade edilebilir

Araştırma sorusu 1: TBMM'nde bulunan ve üye sayısı bakımından önde olan 5 siyasal partinin ideoloji çerçevesinde mevcut algıları nelerdir?

TBMM'sinin milletvekili bakımından önde gelen 5 siyasal partinin siyasal ideoloji bakımından algılarını, araştırmanın bulguları ışığında şu şekilde ifade etmek mümkündür. AKP'nin muhafazakâr ve liberal bir algısının olduğu görülmektedir. CHP'nin Atatürkçü ve sosyal-demokrat bir algısının olduğu görülmektedir. MHP’nin milliyetçi bir algıya sahip olduğu görülmektedir. HDP’nin komünist bir algıya sahip olduğu görülmektedir. İYİ parti ise tam olarak bir ideoloji çerçevesinde algılanamamaktadır. Bu durumu iyi partinin yeni bir parti olmasından kaynaklanabilir lakin araștırma bulgularında en yüksek aldığı yüzde olan $18 \%$ ile sosyal-demokrat görülmektedir.

Araştırma sorusu 2: Siyasal algıların oluşumunda hangi kitle iletişim araçları daha önemli bir röle sahiptir?

Araştırmaya katılan öğrenciler siyasal algının oluşmasında en etkili araçları sırasıyla şu şekilde ifade etmektedir. İlk olarak internet, daha sonrasında kamuoyu araştırmaları ve son olarak ise siyasal miting ve geziler olduğunu ifade etmektedirler. 
Araştırma sorusu 3: Öğrenim görülen alanlara göre siyasal algıların oluşmasında aile ve yakın çevrenin rolü nelerdir?

Siyasal algıların oluşmasında aile ve yakın çevrenin etkisi açısından hakla ilişsiler, reklam ve radyo, televizyon ve sinema alanında öğrenim görenler karasız olduklarını ifade ederken gazetecilik alanında öğrenim görenler aile ve yakın çevrenin siyasal algıların oluşmasında önemli olduğunu düşündüklerini çalışmada belirtmişlerdir.

Yapılan çalışmada teorik bölümde ifade ettiğimiz siyasal açıdan algı yönetimi kurallarına uyulup-uyulmadığı konusunda araştırmaya katılan katılımcılar, çoğu kural için karasızlıklarını veya katıldıklarını ifade etmektedirler. Bu kurallara uymak başarılı bir siyasal algı yönetimi sağlamada fayda sağlayacağı düșünüldüğünde siyasal aktörlerin veya organların, kuralların uygulanması açısından karasız kalan katılımcıları etkileyebilmek için bu kurallara daha fazla yönelmeleri gerekmektedir. Siyasal aktör ve organlar, yapmış oldukları siyasal iletişim çalışmalarını internet aracılıyla hedef kitleye ulaştırmaya daha çok özen göstermeleri gerekmektedir. Bu durumun temel sebebi ise yapılan bu çalışmaya göre siyasal algıların oluşmasında en etkili olan iletişim aracının internet olmasıdır. Böylelikle internet aracılıyla verilen siyasal mesajların hedef kitlenin algısını biçimlendirmede daha kolaylık sağlayacaktır.

Siyasal partiler çalışma sonucunda elde edilen mevcut ideolojik algılarını ve yansıtmak istedikleri ideolojik algı ile algılanan ideolojik algılarını gözlemlemelidirler. Yansıtmak istedikleri algı ile hedef kitlenin algıladığı ideolojik algı farklı ise bu duruma yönelik siyasal iletişim çalıșmaları başlatmalıdırlar ve bu çalışmalarında kitle iletişim araçlarına yer vermelidirler. Özellikle çalışmanın siyasal iletişimde kitle iletişim araçlarının önemi ve mevcut partilerin algılanan ideolojileri hususunda alana katkı sağlayacağı ve algı yönetiminin önemine dikkat çekmesi açısından literatüre katkı sağlayacağı düşünülmektedir.

\section{Kaynakça}

Akay, E. (2014). Kapitalizmin Son Oyunu; Algı Yönetimi, Köklü Değişim Dergisi, 0(117), 29-34

Aziz, A. (2014). Siyasal İletişim. Ankara: Nobel Yayınları.

Bakan, İ. ve Kefe, İ. (2012). Kurumsal Açıdan Algı ve Algı Yönetimi, Kahramanmaraş Sütçü İmam Üniversitesi İktisadi ve İdari Bilimler Dergisi, 2(1), 19-34.

Balcı, Ş. ve Damlapınar, Z. (2014). Seçmenin Zihnindeki Aday İmajını Belirleyen Etmenler, Selçuk Üniversitesi Sosyal Bilimler Dergisi, 4(1), 49-79.

Balcı, Ş. ve Bekiroğlu, O. (2015). Türkiye'de Siyasal Kampanya Uygulamaları, İsmail Çağlar ve Yusuf Özkır (Eds.), Türkiye'de Siyasal İletişim 2007-2015, İstanbul: SETA Siyaset, Ekonomi ve Toplum Araştırmaları Vakfı Yayınları, ss. 11-18

Başarır, M. (2016). Politik Konuşmalardaki İkna ve Üslup Faktörlerinin Seçmenlerin Sosyo Demografik Özellikleri ile Siyasi Tercihlerine göre Karşılaştırması, Uluslararası Sosyal ve Eğitim Bilimleri Dergisi, Cilt 3, Sayı 6, Aralık, 87-105.

Başsoy, İ. (2011). AKP Neden Kazanır? CHP Neden Kaybeder. İstanbul: Pegasus Yayınevi.

Baysal, S. (2010). 'Siyasal İletişimde Bir Halkla İlişkiler E-Ortamı Olarak Sosyal Ağların Kullanımı', Yüksek Lisans Tezi, Ege Üniversitesi, Sosyal Bilimler Enstitüsü, İzmir. 
Berberoğlu, G. (1997). Siyasal Parti Yönetimi. Eskişehir: Anadolu Üniversitesi Yayınları.

Büyüköztürk, Ş. vd. (2008). Bilimsel Araştırma Yöntemleri. Ankara: Pagem Yayınevi.

Callamari, P. ve Reveron, D. (2003). Chine's Use of Perception Management, International Journal of Intelligence and Counter Intelligence, 16, 2003, 1-15.

Canbey, M. (2009). 'Siyasal İletişim Sürecinde Siyasi Parti Liderlerinin Markalaşması Üzerine Bir Analiz', Yüksek Lisans Tezi, Marmara Üniversitesi, Sosyal Bilimler Enstitüsü, İstanbul.

Ceng, E. (2018). Algı Yönetimi Aracı Olarak Twitter Kullanımına İlişkin Siyasal Bir Analiz, Erciyes Üniversitesi İletişim Dergisi, 5(4), 663-689.

Çelik, Y. (2018). Bir Algı Yönetimi Aracı Olarak Tiyatro, Türkiye Sosyal Araştırmalar Dergisi, $22(2), 433-359$

Çitlioğlu, E. (2012). Siyasi Propaganda ve Algı Yönetimi. Ankara: Polpaum Yayınları.

Damlapınar, Z. ve Balcı, Ş. (2005). Seçmenin Zihnindeki Aday İmajını Belirleyen Etkenler: 28Mart 2004 Yerel Seçimleri Alan Araştırması, Selçuk İletişim, 4(1),58-79.

Heywood, A.(2006). Siyaset, (çev. Özipek ve diğerleri), Ankara:Liberte Yayınları

Kazu, E. (2018). 'Algı Yönetimi Perspektifinden Siyasal İletişim ve Lider İlişsisi: Turgut Özal Dönemi Analizi (1983-1989)', Yüksek Lisans Tezi, Gaziantep Üniversitesi, Sosyal Bilimler Enstitüsü, Gaziantep.

Kentel, F.(1991). “Demokrasi, Kamuoyu ve Siyasal İletişime Dair”, Birikim Dergisi, (0)30, 39-44.

Kılıçaslan, E. (2008). Siyasal iletişim, İdeoloji ve Medya İlişkisi. İstanbul: Kriter Yayınevi.

Kışlalı, A. T. (2002). Siyaset Bilimi. Ankara: İmge Kitabevi.

Morris, C. G. (2002). Psikolojiyi Anlamak. (Çev. Belgin Ayvaşık ve Melike Sayıl) Ankara: Türk Psikologlar Derneği Yayınları.

Öksüz, H. (2013). Algı Yönetimi ve Sosyal Medya, İdarecinin Sesi Dergisi, 0(156), 12-15.

Özçelik, M. (2015). 'Siyasal İletişimde Algılama Yönetimi', Yüksek Lisans Tezi, Marmara Üniversitesi, Sosyal Bilimler Enstitüsü, İstanbul.

Özer, M. A. (2008). 21. Yüzyılda Yönetim ve Yöneticiler. Ankara: Nobel Yayınları.

Özer, M. A. (2014). Siyasal İletişimin Etkinliğinde Algılama Yönetiminin Rolü, HAK-IŞ Uluslararası Emek ve Toplum Dergisi, Cilt: 3, Yıl: 3, Sayı: 7, 166-197.

Özodaşık, M. (2009). Kişilerarası İletişim Sürecinde Algı İkna ve Empatik İlişkiler. Konya: Tablet Yayınları.

Payam, M. M. (2018). Güvenlik Bağlamında Güz Kullanımı ve Algılama Yönetimi, Mecmua Uluslararası Sosyal Bilimler Dergisi, 0(5), 15-25.

Saydam, A. (2005). İletişimin Akıl ve Gönül Penceresi: Algılama Yönetimi. İstanbul: Remzi Kitapevi

Saydam, A. (2012). Algı Yönetimi. Ankara: Remzi Kitapevi.

Schecter, D.(2006). Perception Management, http://www. mediachannel. org/views/ dissector/persuasion.shtml 05.01.2006. 
Tutar, H. (2008). Simetrik ve Asimetrik İletişim Bağlamında Örgütsel Algılama Yönetimi. Ankara: Seçkin Yayınları.

Türk, M. S. (2014). Algı Yönetimi, B. Karabulut (Ed.) Algı Yönetimi. İstanbul: Alfa Yayınları.

Türk, M. S. ve Bıyık, A. (2009). Uluslararası Haber Ajanslarının Algı Yönetimi Çalışmaları ve İletişimdeki Dengesiz Yapının Sonuçları, M. Işık ve M. Akdağ, (Ed.).Dünden Bugüne Halkla İlişkiler içinde, Ankara: Eğitim Akademi Yayınları, 323-351.

Uğurlu, Ö. (2004). 'Algı Yönetimi olarak Halkla İlişkiler', Yüksek Lisans Tezi, Gazi Üniversitesi, Sosyal Bilimler Enstitüsü, Ankara.

www.TBMM.gov.tr, Erişim Tarihi: 20/05/2019

www.tarihiolaylar.com, Erişim Tarihi: 17/05/2019 


\title{
Ideological Aspect of the Relationship Between Political Communication and Perception Management Evaluation: Selçuk University Faculty of Communication
}

\author{
Makbule Evrim Gülsünler (Assoc. Prof. Dr.) \\ Şerif Tahmaz
}

\section{Extended Abstract}

In addition to military, commercial, geographical and educational applications, perception management techniques have been frequently applied in the political world in recent years. Political actors and organs; they develop their messages and marketing plans using perception management techniques to spread their messages and increase their masses. Managing and directing communication within the framework of perception management will help us to shape the desired behavior politically, reach the main goal, strengthen our political image and spread the political idea to the target audience. This is the main point of the relationship between political communication and perception management. These objectives, which are realized within the scope of political communication and perception management, both make the political actor or the body desire to power, which is the main objective, and the value of the political structure against the voters increases and creates an environment of goodwill in case of crisis. Therefore, well planned and planned with the right timing, perception management practices in the political framework will benefit the political actors and organs in achieving the ultimate goal (Türk and Bıyık, 2009, p.326-327).

This study, which deals with the relationship between political communication and perception management, we see that political actors and organs benefit from many areas for their desire to come to power, which is the main purpose. These areas include relations with rights, advertising, propaganda, image management, perception management and so on. areas. The most notable of these areas is the concept of perception management. Perception management is needed to differentiate in the political arena and to direct political perceptions. Political actors and organizations should inform, direct and supervise their environment in order to manage the perception well within the scope of the communication they have established with the internal-dental environment. It is very difficult for the people or the masses who have not got enough information about the political actors and organizations and have not been able to communicate at the required level to have a positive perception towards the relevant political actors and organizations.

Recently, the rules of perception management within the framework of political communication have increased the competition in the political field and created an awareness by diversifying the activities related to this field. Because the perceptions have been understood to be successful in managing this field and has become the indispensable of every party and leader in this field. In this context, perception management in political communication "Bringing the target audience into a process of believing and convincing that they will consent on a desired idea and purpose. (Akay, 2014, p.30).

In this study, The Justice and Development Party (AKP), Republican and People's Party (CHP), Nationalist and Movement Party (MHP), Good Party and Democratic Party of Peoples (HDP), (TBMM.gov.tr) and the voters' perceptions of political campaigns in the 
2019 local elections. Thus, this research is important both for political actors, political organs and voters and to contribute to the literature. In this study, it is aimed to reveal the perceptions of Selcuk University Faculty of Communication students towards political campaigns, the communication tools and methods effective in the formation of political perceptions and the current perceptions of political parties within the framework of ideology.

This study aimed to determine the political perceptions of Selcuk University Faculty of Communication students it is a research based on quantitative data and general survey model and relational survey model.

It is possible to state the limitations of the research as follows.

- In terms of the universe of the research, it was limited to the students of the Faculty of Communication at Selçuk University.

- The study was limited to a questionnaire, a data collection tool.

- There is a limitation within the scope of the study (29 April-17 June 2019).

The tools and methods that the participants perceived as very important in the formation of political perceptions, rallies and trips organized by political actors and organs, public surveys and the Internet. Therefore, utilizing the internet tool while applying perception management strategies and techniques from the political point of view will contribute greatly to achieving the desired purpose.

It was observed that most of the participants had a conservative perception towards the Justice and Development Party, a nationalist perception towards the Nationalist Movement Party, a social-democratic and Kemalist perception towards the Republic and People's Party and a communist perception towards the Democratic Party of Peoples. The GOOD Party, on the other hand, was seen on average in both nationalist and social democratic ideology. In terms of the effect of family and close environment on the formation of political perceptions, those studying in the field of right relations, advertising and radio, television and cinema stated that they were indecisive, while those studying in the field of journalism stated that they thought that family and close environment were important in the formation of political perceptions. It is thought that the study will contribute to the field in terms of the importance of mass media in political communication and perceived ideologies of existing parties and will contribute to the literature in order to draw attention to the importance of perception management.

Keywords: Politics, Communication, Perception Management 
